\title{
Painful purple nodule on the right thigh-Answer
}

\author{
André Oliveira ${ }^{1}$, Susana Brás ${ }^{1}$, Adelaide Milheiro², Jorge Cardoso ${ }^{1}$
}

\begin{abstract}
1 Department of Dermatology, Hospital de Curry Cabral—Centro Hospitalar de Lisboa Central, Lisboa, Portugal
2 Department of Pathology, Hospital de Curry Cabral—Centro Hospitalar de Lisboa Central, Lisboa, Portugal
\end{abstract}

Citation: Oliveira A, Brás S, Milheiro A, Cardoso J. Painful purple nodule on the right thigh-Answer. Dermatol Pract Concept 2015;5(3):7. doi: 10.5826/dpc.0503a 07

Copyright: $@ 2015$ Oliveira et al. This is an open-access article distributed under the terms of the Creative Commons Attribution License, which permits unrestricted use, distribution, and reproduction in any medium, provided the original author and source are credited.

Corresponding author: André Oliveira, MD, Department of Dermatology, Hospital de Curry Cabral—Centro Hospitalar de Lisboa Central, Rua da Beneficência nº8, 1069-166, Lisboa, Portugal. Tel. +35 1912561666; Fax.+35 1217924392. E-mail: andre.oliveira@sapo.pt

Below is the answer to the quiz by Dr. Oliveira et al presented in the previous issue of Dermatology Practical \& Conceptual [2015;5(2):15].

Congratulations to Dr. Darshan Karia (email:darshan karia3@gmail.com),whowas the first to send us the correct answer!

\section{Answer}

Diagnosis: Extradigital solitary glomus tumor

\section{Clinical course}

The patient had no evidence of recurrence during 12 months of follow-up.

\section{Answer and explanation}

Glomus tumors are neoplasms of the normal glomus body. This structure is a neuromyoarterial body composed of an afferent arteriole and an efferent venule with multiple interconnections. Contractility of glomus cells occurs after temperature changes are sensed by nerves within the glomus body, hence its importance in local blood flow regulation $[1,2]$. Glomus tumors are rare corresponding to $1,6 \%$ of all soft tissue tumors. They are usually solitary, presenting as a blue to pink, soft nodule associated with a classic triad of symptoms: pain, pinpoint tenderness and cold sensitivity. These tumors are frequently located on the extremities, mostly in the subungueal areas of the digits. Extradigital locations include upper and lower extremities, trunk and less commonly the face. Therefore, glomus tumors in extradigital locations may represent a diagnostic challenge resulting in misdiagnosis of these lesions $[3,4]$.

Dermoscopy features of extradigital glomus tumors have rarely been documented [5]. In our case, central purple homogeneous area correlates to enlarged vessels and surrounding white patch probably corresponds to fibrous structures. While not specific, theses findings may represent an additional clue to complement the difficult diagnosis of glomus tumors in a less common location. Accurate diagnosis of extradigital glomus tumors is important to avoid long diagnostic delays, providing an early adequate surgical treatment and diminishing associated local chronic pain.

\section{References}

1. Schiefer TK, Parker WL, Anakwenze OA, Amadio PC, Inwards CY, Spinner RJ. Extradigital glomus tumors: a 20-year experience. Mayo Clin Proc 2006; 81:1337-44.

2. Naverson DN, Trask DM, Watson FH, Burket JM. Painful tumors of the skin: “LEND AN EGG”. J Am Acad Dermatol 1993;28:298300.

3. Lee DW, Yang JY, Chang S, et al. Clinical and pathological characteristics of extradigital and digital glomus tumours: a retrospective comparative study. J Eur Acad Dermatol 2011;25:1392-97.

4. Chun JS, Hong R, Kim JA. Extradigital glomus tumor: A case report. Mol Clin Oncol 2014;2:237-39.

5. Ito T, Yoshida Y, Furue M, Yamamoto O. Solitary nodule on the nose. Acta Derm Venereol 2013;93:379-81. 